\title{
A preliminary evaluation of the San Pedro daisy (Lasianthaea podocephala) tuber powder, as a feed additive on the intensive culture of shrimp (Litopenaeus vannamei) under laboratory conditions
}

\author{
Marcel Martínez-Porchas ${ }^{1}$, Enrique Israel Noreña-Rivera ${ }^{2}$, Luis Rafael Martínez-Córdova ${ }^{3}$ \\ José Antonio Lopez-Elias ${ }^{3}$, Fernando Mendoza-Cano ${ }^{3}$ \\ Lorena Bringas-Alvarado ${ }^{3}$ \& María Elena Lugo-Sánchez ${ }^{1}$ \\ ${ }^{1}$ Centro de Investigación en Alimentación y Desarrollo \\ Km 0.6 Carretera a La Victoria, Hermosillo, Sonora, México \\ ${ }^{2}$ Licenciatura en Biología de la Universidad de Sonora, Luis Donaldo Colosio s/n \\ entre Reforma y Sahuaripa, Hermosillo, Sonora, 83000, México \\ ${ }^{3}$ Departamento de Investigaciones Científicas y Tecnológicas, Universidad de Sonora \\ Luis Donaldo Colosio s/n entre Reforma y Sahuaripa, Hermosillo, Sonora, 83000, México
}

\begin{abstract}
An experimental study was carried out during seven weeks to preliminarily evaluate the effect of the dietary inclusion of powder from the tuber Lasianthaea podocephala, commonly known as the San Pedro daisy or pionilla, as a feed additive on the production parameters, food consumption, and nutritional condition of the white shrimp, Litopenaeus vannamei, intensively farmed under laboratory conditions. Hypothetically, the additive should improve these parameters as it does when used for humans. The powder was included at different levels (0 [Control], 0.2 [T1] and $1 \mathrm{~g} \mathrm{~kg}^{-1}$ [T2]) in a commercial shrimp feed. The tuber powder exhibited a free amino acid profile being arginine $\left(8.59 \mathrm{mg} \mathrm{g}^{-1}\right)$ and glutamine $\left(3.36 \mathrm{mg} \mathrm{g}^{-1}\right)$ the most abundant. Feed consumption was not influenced by any treatment; however, the survival and the overall production responses were higher in both treatments using the powder (T1 and T2) compared to the control. No significant differences were detected in muscle concentrations of lactate and glucose, although higher protein and lower cholesterol concentrations were observed in shrimp reared in the control. The lower cholesterol concentration of shrimp from the control could be associated to a poor nutritional status. In conclusion, addition of the powder of San Pedro daisy did not improve the feed consumption, but apparently had a positive effect on survival, production response and nutritional status of shrimp. These responses could be associated to an hypothetic effect of some plant components at a nutritional-molecular level, or to a possible antimicrobial effect; however, further specific studies are needed.
\end{abstract}

Keywords: dietary attractants, plant tuber, plant additives, vegetal additives, shrimp nutrition, muscle parameters.

\section{Evaluación preliminar del polvo de tubérculo de San Pedro daisy (Lasianthaea podocephala), como aditivo alimenticio en el cultivo intensivo de camarón (Litopenaeus vannamei) bajo condiciones de laboratorio}

RESUMEN. Se realizó un experimento durante siete semanas para evaluar, de manera preliminar, el efecto de la inclusión dietaria del polvo de tubérculo Lasianthaea podocephala, comúnmente conocida como San Pedro daisy o pionilla, como aditivo alimenticio, sobre los parámetros de producción, consumo de alimento, y condición nutricional del camarón blanco (Litopenaeus vannamei), cultivado bajo condiciones de laboratorio. Hipotéticamente, el aditivo debiera mejorar estos parámetros como lo hace cuando es usado en humanos. El polvo fue incluido a diferentes niveles (0 [Control], 0,2 [T1] y $1 \mathrm{~g} \mathrm{~kg}^{-1}$ [T2]), en un alimento comercial para camarón. El polvo de la planta mostró un perfil de aminoácidos donde la arginina $\left(8,59 \mathrm{mg} \mathrm{g}^{-1}\right)$ y glutamina (3,36 $\left.\mathrm{mg} \mathrm{g}^{-1}\right)$ fueron los más abundantes. El consumo de alimento no fue influenciado por alguno de los tratamientos; sin embargo, la supervivencia y, en general, las respuestas productivas fueron mejores en ambos tratamientos que utilizaron el polvo (T1 y T2) en comparación con el control. No se detectaron diferencias significativas en las concentraciones musculares de lactato y glucosa, aunque se observaron altas y bajas concentraciones de proteína y colesterol en camarones criados en el tratamiento control. La baja concentración de colesterol en los camarones del tratamiento control podría estar asociada a un pobre estado nutricional. La 
inclusión del polvo de la planta San Pedro daisy no incrementó el consumo de alimento, pero aparentemente tuvo un efecto positivo en la supervivencia, respuesta productiva y estado nutricional del camarón. Estas respuestas podrían asociarse a un hipotético efecto de algún componente de la planta a nivel nutricionalmolecular, o a un posible efecto antimicrobiano; sin embargo, se necesitan estudios específicos adicionales.

Palabras clave: atractantes dietarios, tubérculo de planta, aditivos de plantas, aditivos vegetales, nutrición de camarón, parámetros musculares.

Corresponding author: Luis Rafael Martínez-Córdova (lmtz@guaymas.uson.mx)

\section{INTRODUCTION}

One of the problems faced by shrimp farmers is the occasional low feed consumption associated to diverse factors such as molting (Muhlia-Almazan \& GarcíaCarreño, 2002), stress (Mercier et al., 2006), farming temperature (Hewitt \& Duncan, 2002), low attractability and/or palatability of offered feed (Samocha et al., 2004), among others. In particular, low feed consumption may result in deterioration of the nutritional condition of the farmed organisms, leading to poor responses of growth, survival, biomass, and feed conversion ratio. In consequence, the above-mentioned scenario causes negative impacts on the economic feasibility of farms.

Feed formulations have been complemented with diverse kind of attractants, to solve the abovementioned problems (Tacon, 1989); these additives can be from animal or vegetal origin, and in some cases, synthetic. Herein, several products of animal origin including fish meals, fish oils, squid, fish hydrolysates and others, have shown good performance as feed attractants for the white shrimp, Litopenaeus vannamei (Nunes et al., 2006), blue shrimp, L. stylirostris (Suresh et al., 2011), crayfish, Cherax quadricarinatus (Saoud et al., 2008) and other decapods. The disadvantages of these products are their high costs and in some cases their low availability.

Several vegetal products have been also evaluated as additives in shrimp feedstuffs for diverse purposes. For instance, vegetal-derived products have been used as antimicrobial, immunestimulant and probiotic additives (Zadeh et al., 2010; Vaseeharan et al., 2011; Harikrishnan et al., 2012). Maqsood et al. (2013) documented that plant polyphenolic compounds can serve as potential additives for preventing quality deterioration or to retain the quality of fish and fish products. However, information about the use of vegetal additives as attractants in shrimp aquafeeds is yet scarce. Silva-Neto et al. (2012) reported the effectiveness of Spirulina meal as attractant for $L$. vannamei, included at very low levels in the formulated feed.
Purified substances such as L-amino acids or biogenic amines (Mendoza et al., 1997; Smith et al., 2005), have shown their potential as attractants for farmed shrimp or fishes. Some tubers as potatoes and others contain high concentrations free amino acids (FAA), and consequently could have potential for such purpose (Brierley et al., 1999).

A wild plant, Lasianthaea podocephala (Asterales: Asteraceae), commonly known as San Pedro daisy, pionilla in Spanish, inhabits the north of Mexico. Its tuber is used in the traditional human herbal medicine as appetizer, and to control microbial and/or parasite diseases. Preliminary unpublished experiments revealed that $L$. podocephala tuber contained FAA such as glutamine and arginine, which are considered as attractants in the aquatic medium.

Based on the above information, it is plausible to hypothesize that the inclusion of an extract of the plant can similarly serve for shrimp as efficiently as for humans. The aim of our experiments was to evaluate the effect of two inclusion levels of $L$. podocephala tuber powder in a commercial shrimp feedstuff, on the feed consumption, production parameters, and nutritional condition of the white shrimp, L. vannamei, intensively cultured under laboratory conditions.

\section{MATERIALS AND METHODS}

The study was conducted over seven weeks in the facilities of DICTUS, the Department of Scientific and Technological Research of the University of Sonora, at Hermosillo, Sonora, Mexico.

A single-factor experimental design, with three replicates per treatment, was performed. Treatments consisted of two levels of inclusion of L. podocephala tuber powder in a commercial shrimp feed, with $35 \%$ of crude protein (Camaronina 35, by Agribrand Purina $^{\mathrm{R}}$ ), and a control without the inclusion of the product. Nine plastic cages $(60 \mathrm{~L}$ in capacity and $40 \mathrm{~L}$ of operative water volume) with cap and placed in a metallic ad-hoc structure were used as experimental units. Shrimp postlarvae (Pl-12), with an individual weight of $0.06 \mathrm{~g}$, obtained from a commercial shrimp 
hatchery located near to our laboratory were stocked at a rate of 25 organisms per unit $\left(125 \mathrm{~m}^{-2}\right)$. Continuous aeration was applied to each unit along the trial to maintain dissolved oxygen (DO) levels above $4.5 \mathrm{mg} \mathrm{L}^{-1}$. A weekly water exchange of $25 \%$ was performed, sufficient to discharge the unconsumed feed, feces and molts, and to maintain an adequate water quality.

Physical and chemical parameters of the water were monitored. Temperature, salinity, dissolved oxygen, and $\mathrm{pH}$ were estimated daily by using a multiparameter sensor YSI 6600; total ammonium nitrogen (TAN), nitrite-nitrogen $\left(\mathrm{N}-\mathrm{NO}_{2}\right)$, nitratenitrogen $\left(\mathrm{N}-\mathrm{NO}_{3}\right)$, and orthophosphates $\left(\mathrm{P}-\mathrm{PO}_{4}\right)$ were quantified weekly by spectrophotometry with a HACH DR-4000 equipment.

For the preparation of the experimental feeds, the tubers were cut in small slices with a knife $(\sim 0.5 \mathrm{~cm})$, and dried in a stove at $60^{\circ} \mathrm{C}$ for $12 \mathrm{~h}$; afterwards, the tuber pieces were grinded in an industrial mill (GE Motors \& Industrial Systems), up to 40 microns. The tuber powder was incorporated into shrimp feed. A commercial feed (Camaronina, Purina ${ }^{\circledR}$ ) was pulverized in a Hobbart ${ }^{(\mathbb{B}}$ mill, and mixed to the powder at rates of 2 and $10 \mathrm{~g} \mathrm{~kg}^{-1}$ (treatments $\mathrm{T} 1$ and $\mathrm{T} 2$, respectively). Finally, hot water was added to reconstitute the feed using a pelletizer mill. The pellets were dried for $12 \mathrm{~h}$, cut at $2 \mathrm{~mm}$ in length, and passed through a mesh to eliminate powder. A similar amount of commercial feed was submitted to the same pulverization and reconstitution process, but no tuber powder was added.

Feed was supplied twice a day in feeding trays $(10 \times 10 \mathrm{~cm})$, and the ration was daily adjusted considering the apparent consumption, as suggested by Salame (1993). Unconsumed feed, feces, molts and dead organisms were siphoned daily out of the units.

At the end of the trial, all shrimp were counted and weighed (Sartorious ${ }^{\mathrm{R}}$ balance/precision $0.01 \mathrm{~g}$ ) to determine the final weight, survival and biomass. The feed conversion ratio (FCR) was calculated as the amount of feed consumed over the gained biomass. Specific growth rate was calculated as:

$$
\mathrm{SGR}=\left[\frac{\ln (\text { Final.weight })-\ln (\text { Initial.weight })}{\mathrm{T}_{1}-\mathrm{T}_{0}}\right] 100
$$

where $T_{1}-T_{0}$ was considered as the number of days of the experiment.

Samples of 10 individuals were taken from each unit, de-headed and peeled; then, $100 \mathrm{mg}$ of muscle were macerated and homogenized with $1 \mathrm{~mL}$ deionized water. Muscle homogenates were centrifuged at $10^{\circ} \mathrm{C}$ and $10000 \mathrm{rpm}$ for $30 \mathrm{~min}$ (SIGMA 2-16K). Finally, samples of the supernatant $(10 \mu \mathrm{L})$ were taken to estimate the concentration of protein, glucose, lactate and cholesterol. The quantifications were assessed by following the microplate technique proposed by Hernández-Lopez (2001), using specific commercial kits (RANDOX) for each parameter.

The free amino acid (FAA) profile of the tuber powder was estimated following the method described by Vázquez-Ortiz et al. (1995) with modifications. One $\mathrm{g}$ of powder was homogenized with $20 \mathrm{~mL}$ of trichloroacetic acid (TCA 7.5\%); thereafter, $5 \mathrm{~g}$ of the homogenate were mixed and homogenized with 100 $\mathrm{mL}$ of TCA $(7.5 \%)$. The sample was then centrifuged at $4^{\circ} \mathrm{C}$ and $4000 \mathrm{rpm}$ for 15 min (Beckman J2-21). The supernatant was removed and filtered through Whatman $\mathrm{N}^{\mathrm{o}} 1$ filter. Finally, the filtered sample was analyzed in a HPLC using an automated injection system (Aligent 1100); $10 \mu \mathrm{L}$ of sample were mixed with $10 \mu \mathrm{L}$ of OPA (o-phtalaldehyde) and analyzed.

Data of water quality parameters, as well as those of final weight, FCR, protein, glucose and lactate, were analyzed by a one-way ANOVA, as they showed to be normal (Kolmogorov-Smirnov), and homoscedastic (Bartlett). Post-hoc comparisons were performed by a Tukey test. Final biomass and cholesterol data were analyzed by a non-parametric Kruskal-Wallis test (Zar, 1999). Survival and SGR were analyzed by a chi-square test, while feed consumption was analyzed by one-way repeated measures ANOVA. A significance level of $P<0.05$ was considered.

\section{RESULTS}

Sixteen different FAA were found in the San Pedro daisy powder, from which arginine $\left(8.6 \mathrm{mg} \mathrm{g}^{-1}\right)$, glutamine $\left(3.4 \mathrm{mg} \mathrm{g}^{-1}\right)$, tyrosine $\left(0.7 \mathrm{mg} \mathrm{g}^{-1}\right)$ and histidine $\left(0.5 \mathrm{mg} \mathrm{g}^{-1}\right)$ were the most abundant (Table $1)$.

No significant differences among treatments were detected for DO (4.5-4.9 $\left.\mathrm{mg} \mathrm{\textrm {L } ^ { - 1 }}\right)$, temperature $\left(27.5^{\circ} \mathrm{C}\right)$, salinity $(35.5-35.7 \mathrm{psu})$, TAN $(0.29-0.38 \mathrm{mg}$ $\left.\mathrm{L}^{-1}\right), \mathrm{N}-\mathrm{NO}_{2}\left(0.23-0.26 \mathrm{mg} \mathrm{L} \mathrm{L}^{-1}\right)$ and $\mathrm{N}^{-\mathrm{NO}_{3}}(2.7-3.3$ $\left.\mathrm{mg} \mathrm{L} \mathrm{L}^{-1}\right)$. However, $\mathrm{P}_{-1} \mathrm{PO}_{4}$ levels were significantly higher in $\mathrm{C}\left(1.2 \mathrm{mg} \mathrm{L}^{-1}\right)$, compared to T1 and T2 (0.4$\left.0.6 \mathrm{mg} \mathrm{L}^{-1}\right)$. $\mathrm{pH}$ was also higher in $\mathrm{C}(6.9)$ compared to $\mathrm{T} 1$ and $\mathrm{T} 2(6.7)$.

Regarding production parameters, some significant differences were observed among treatments and the control (Fig. 1). Survival was significantly higher in both treatments (T1 \& T2), compared to the control. The final weight reached by shrimp was significantly 
Table 1. Free aminoacid profile of San Pedro daisy (Lasianthaea podocephala) tuber powder. SD: standard deviation.

\begin{tabular}{lcc}
\hline Aminoacid & $\begin{array}{c}\text { Concentration } \\
\left(\mathrm{mg} \mathrm{g}^{-1}\right)\end{array}$ & $\mathrm{SD}$ \\
\hline Aspartic acid & 0.000 & 0.000 \\
Glutamic Acid & 0.310 & 0.006 \\
Glutamine & 3.361 & 0.207 \\
Serine & 0.050 & 0.002 \\
Asparagine & 0.302 & 0.011 \\
Histidine & 0.516 & 0.164 \\
Arginine & 8.595 & 0.573 \\
Glicine & 0.097 & 0.013 \\
Treonine & 0.192 & 0.027 \\
Taurine & 0.114 & 0.014 \\
Alanine & 0.000 & 0.000 \\
Tyrosine & 0.695 & 0.015 \\
Metionine & 0.000 & 0.000 \\
Valine & 0.039 & 0.004 \\
Phenylalanine & 0.006 & 0.002 \\
Isoleucine & 0.001 & 0.000 \\
Leucine & 0.007 & 0.000 \\
Lisine & 0.054 & 0.007 \\
\hline
\end{tabular}

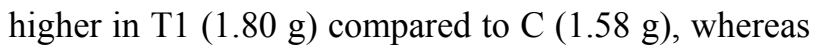
$\mathrm{T} 2(1.63 \mathrm{~g})$ was not statistically different from $\mathrm{T} 1$ and C. However, no significant differences were detected for SGR among C $\left(6.1 \%\right.$ day $\left.^{-1}\right)$, T1 $\left(6.5 \%\right.$ day $\left.^{-1}\right)$ and T2 $\left(6.4 \%\right.$ day $\left.^{-1}\right)$. The final biomass was almost 2 -fold times greater in $\mathrm{T} 1$ and $\mathrm{T} 2$ compared to $\mathrm{C}$, whereas FCR was around $50 \%$ higher in C, compared to both treatments. Feed consumption increased through time, but it was statistically similar among treatments (Fig. 2).

Regarding to tissue parameters, no significant differences among treatments were detected for glucose (3-5 $\left.\mathrm{mg} \mathrm{g}^{-1}\right)$, and lactate $\left(2.0-3.5 \mathrm{mg} \mathrm{g}^{-1}\right)$ (Fig. $3)$. However, the protein level was higher in shrimp from the control $\left(\sim 80 \mathrm{mg} \mathrm{g}^{-1}\right)$ compared to both treatments $\left(55-65 \mathrm{mg} \mathrm{g}^{-1}\right)$; in contrast, cholesterol levels were significantly higher in $\mathrm{T} 1\left(5.5 \mathrm{mg} \mathrm{g}^{-1}\right)$ and $\mathrm{T} 2\left(12.4 \mathrm{mg} \mathrm{g}^{-1}\right)$ compared to the control $\left(0.9 \mathrm{mg} \mathrm{g}^{-1}\right)$ (Fig. 3).

\section{DISCUSSION}

The relatively high content of some FAA in the tuber powder, such as arginine, glutamine, tyrosine and histidine, initially suggested that it could have a good potential as attractant for aquafeeds, considering that FAA plays an important role on the attractability and chemoreception of aquatic organisms (Velez et al., 2007; Silva-Neto et al., 2012). However, the feed consumption observed herein, did not support the above hypothesis, considering that consumption was not increased by the addition of the tuber powder in any of the treatments. Surprisingly, the overall production response was better in shrimp fed on diets containing 2 or $10 \mathrm{~g} \mathrm{~kg}^{-1}$ of the tuber powder, compared to those fed on the commercial diet without the ingredient.

In general, the survival was low in all treatments $(\leq 50 \%)$, probably associated to crowding stress caused by the high density and cannibalism, considering that water quality parameters were adequate and not altered in any treatment. However, the lower survival and production response of shrimp reared in control treatment could be associated to a possible malnutrition status; for instance, shrimp from control exhibited higher protein and lower cholesterol concentrations compared to those from $\mathrm{T} 1$ and $\mathrm{T} 2$. Low cholesterol concentrations have been associated to poor nutritional status of crustaceans (Pascual et al., 2006), because of the versatile physiological roles that cholesterol can play, and considering that it cannot be biosynthesized de novo by crustaceans (Palacios \& Racotta, 2007). Moreover, the cholesterol levels found in shrimp from the control are lower than those of shrimp (L. vannamei) undergoing reproductive exhaustion (Palacios et al., 1999); thus, the low cholesterol level is a serious scenario for shrimp growth and survival, because the lack of cholesterol per se does not cause mortality, but increases the physiological and immunological susceptibility of shrimp.

The inclusion of the tuber powder did not influence the feed consumption of shrimp; however, considering the production response and some of the physiological parameters measured, it is possible that some components of the powder could have an effect on the cholesterol absorption by shrimp. To confirm such hypothesis, further studies are needed, as well as to isolate the different components of the plant tuber.

In addition, the better survival and production response of shrimp from $\mathrm{T} 1$ and $\mathrm{T} 2$ could be related to a better health status caused by the addition of the powder. For instance, some plant tubers have been reported to exhibit antimicrobial properties (Kim et al., 2005), improving the resistance of shrimp to diverse pathogens, similarly as reported for some microbial immunostimulants (Flores-Miranda et al., 2011). One of the few studies about L. podocephala reported that it contains enantiomer, (R)-(-)curcuphenol, which has exhibited activity against Staphylococcus aureus and Vibrio anguillarum (Ghisalberti et al., 1979). However, the study of additional parameters is necessarily to evaluate the health status of shrimp. 

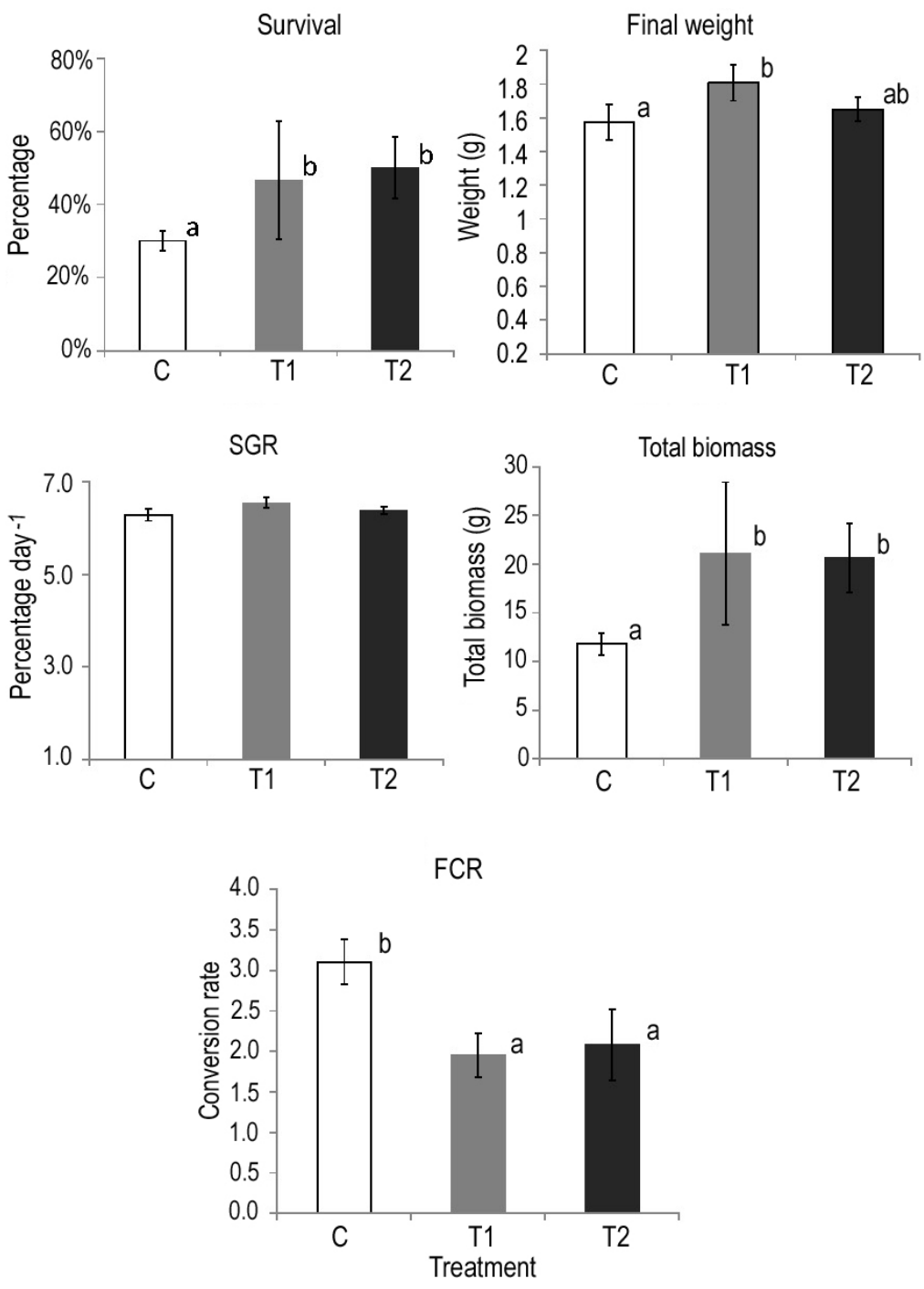

Figure 1. Production response of white shrimp postlarvae fed on commercial diets containing 0 (C), 2 (T1) and 10 (T2) g $\mathrm{kg}^{-1}$ of San Pedro daisy tuber powder (Lasianthaea podocephala). SGR: specific growth rate, FCR: feed conversion ratio. Different letters above bars indicate significant differences $(P<0.05)$

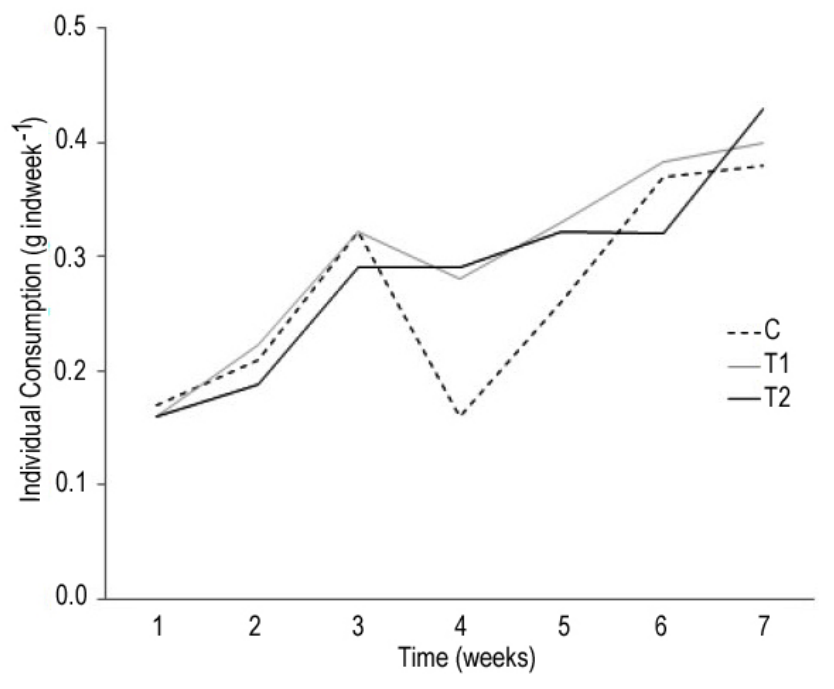

Figure 2. Individual feed consumption per week, of shrimp fed on commercial diets containing 0 (C), 2 (T1) and 10 (T2) $\mathrm{g} \mathrm{kg}^{-1}$ of San Pedro daisy tuber powder (Lasianthaea podocephala). Y-axis indicates the weekly amount of feed consumed by shrimp. 

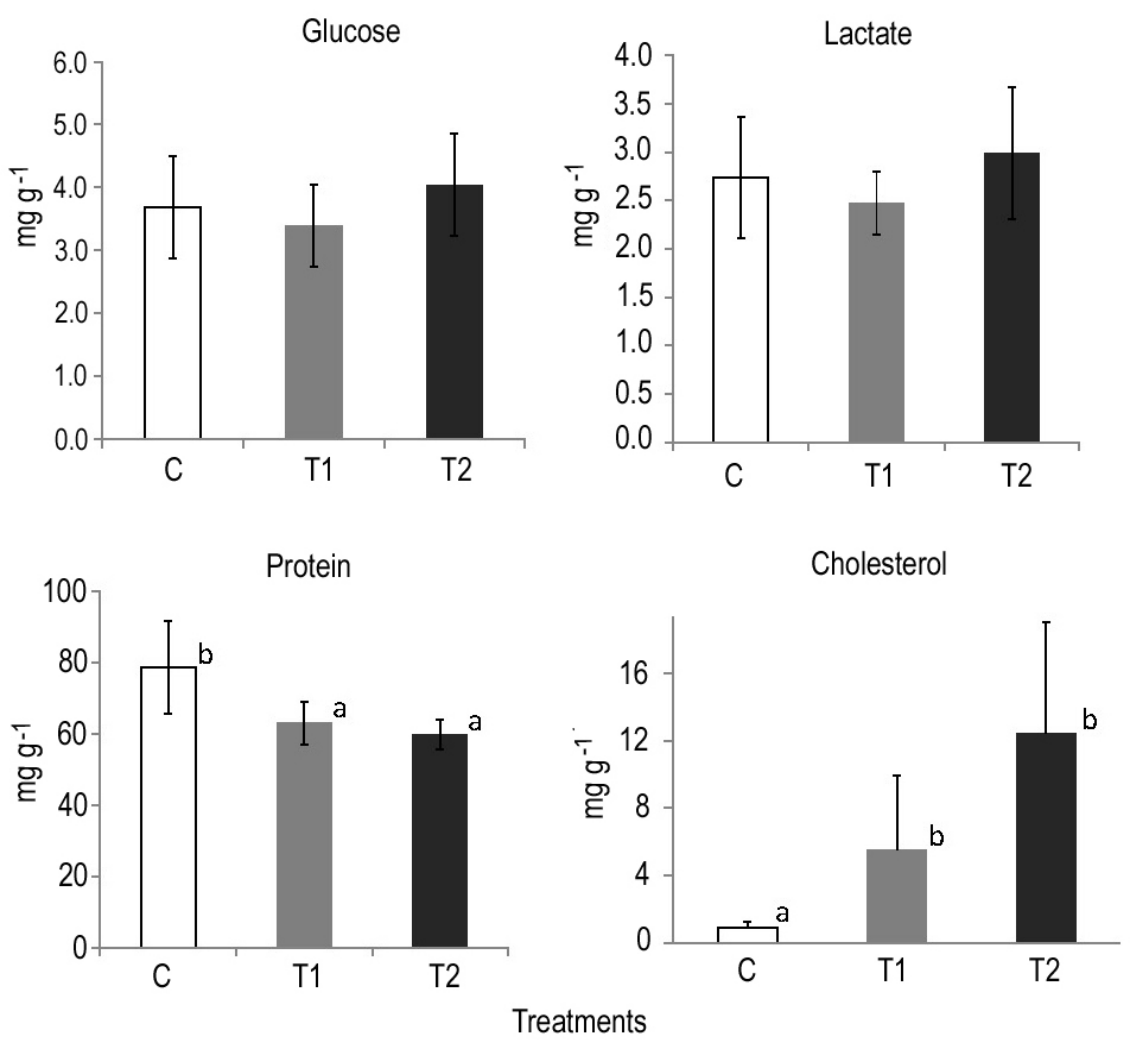

Figure 3. Concentration of different tissue parameters of shrimp fed on commercial diets containing 0 (C), 2 (T1) and 10 (T2) $\mathrm{g} \mathrm{kg}^{-1}$ of San Pedro daisy tuber powder (Lasianthaea podocephala).

Despite the fact that our results demonstrated that the dietary inclusion of San Pedro daisy did not promote the feed consumption by shrimp, the data suggest that its inclusion have a positive effect on the survival and growth response of shrimp reared under high densities. Thus, it is important to evaluate the particular properties of the plant that enhanced the survival, production response and cholesterol concentration in muscle of shrimp. Finally, the plant tuber could be considered as a source of arginine and glutamine for other purposes besides aquaculture.

\section{ACKNOWLEDGEMENTS}

The authors are grateful to Lauro Mercado for his assistance during the experimental period.

\section{REFERENCES}

Brierley, E.R., P.L.R. Bonner \& A.H. Cobb. 1999. Factors influencing the free amino acid content of potato (Solanum tuberosum L.) tubers during prolonged storage. J. Sci. Food Agricult., 70: 515-525.

Flores-Miranda, M.C., A. Luna-González, A.I. CampaCórdova, H.A. González-Ocampo, J.A. Fierro-
Coronado \& B.O. Partida-Arangure. 2011. Microbial immunostimulants reduce mortality in whiteleg shrimp (Litopenaeus vannamei) challenged with Vibrio sinaloensis strains. Aquaculture, 320: 51-55.

Ghisalberti, E., P. Jefferies \& A. Stuart. 1979. The absolute configuration of a sesquiterpene enone from Stevia purpurea and a phenol from Lasianthaea podocephala. Austr. J. Chem., 32: 1627-1630.

Harikrishnan, R., J.S. Kim, C. Balasundaram, C. Jawahar \& M.S. Heo. 2012. Effect of Mangifera indica kernel-enriched feed on immune response of Penaeus indicus aginst white spot syndrome virus (WSSV). Aquacult. Int. Published online, DOI 10.1007/s10499-012-9535-3.

Hernández-López, J. 2001. Diseño de técnicas para la cuantificación de moléculas plasmáticas de camarón. Tesis Doctoral en Ciencias. Centro de Investigación en Alimentación y Desarrollo, A.C. Hermosillo, Sonora, $104 \mathrm{pp}$.

Hewitt, D.R. \& P.F. Duncan. 2002. Effect of high water temperature on the survival, moulting and food consumption of Penaeus (Marsupenaeus) japonicus (Bate, 1888). Aquacult. Res., 32: 305-313.

Kim, J.Y., S.C. Park, M.H. Kim, H.T. Lim, Y. Park \& K. Hahm. 2005. Antimicrobial activity studies on a 
trypsin-chymotrypsin protease inhibitor obtained from potato. Biochem. Biophys. Res. Comm., 330: 921-927.

Maqsood, S., S. Benjakul \& F. Shahidi. 2013. Emerging role of phenolic compounds as natural food additives in fish and fish products. Crit. Rev. Food Sci. Nutr., 53: 162-179.

Mendoza, R., J. Mercier, J. Verde \& C. Aguilera. 1997. Quimioatracción en crustáceos: papel de las moléculas biogénicas. In: L.E. Cruz-Suárez, D. Rique-Marie \& R. Mendoza. (eds.). Memorias del III Simposium Internacional de Nutrición Acuícola. Monterrey, pp. 365-401.

Mercier, L., E. Palacios, A. Campa-Córdova, D. TovarRamírez, R. Hernández-Herrera \& I. Racotta. 2006. Metabolic and immune response in Pacific whiteleg shrimp Litopenaeus vannamei exposed to a repeated handling stress. Aquaculture, 258: 633-640.

Muhlia-Almazan, A. \& F. Garcia-Carreño. 2002. Influence of molting and starvation on the synthesis of proteolytic enzimes in the midgut gland of the white shrimp, Litopenaeus vannamei. Comp. Biochem. Physiol. B, 133: 383-394.

Nunes, A.J.P., M.V.C. Sá, F.F. Andriola-Neto \& D. Lemos. 2006. Behavioral response to selected feed attractants and stimulants in Pacific white shrimp, Litopenaeus vannamei. Aquaculture, 260: 244-254.

Palacios, E., C.I. Pérez-Rostro, J.L. Ramírez, A.M. Ibarra \& I.S. Racotta. 1999. Reproductive exhaustion in shrimp (Penaeus vannamei) reflected in larval biochemical composition, survival and growth. Aquaculture, 171: 309-321.

Palacios, E. \& I.S. Racotta. 2007. Salinity stress test and its relation to future performance and different physiological responses in shrimp postlarvae. Aquaculture, 268: 123-135.

Pascual, C., A. Sánchez, E. Zenteno, G. Cuzon, G. Gabriela, R. Brito, R. Gelabert, E. Hidalgo \& C. Rosas 2006. Biochemical, physiological, and immunological changes during starvation in juveniles of Litopenaeus vannamei. Aquaculture, 251: 416-429.

Salame, M. 1993. Feeding trays in penaeid shrimp ponds. Aquacult. Mag., 19: 59-63.

Samocha, T.L., D.A. Davis, I.P. Saoud \& K. DeBault. 2004. Substitution of fish meal by co-extruded soybean poultry by-products in practical diets for the Pacific white shrimp, Litopenaeus vannamei. Aquaculture, 231: 197-203.

Received: 30 September 2012; Accepted: 30 May 2013
Saoud, I.P., L.J. Rodgers, D.A. Davis \& D.B. Rouse. 2008. Replacement of fish meal with poultry by-product meal in practical diets for redclaw crayfish (Cherax quadricarinatus). Aquacult. Nutr., 14: $139-142$.

Silva-Neto, J.F., A.J. Pinto-Nunes, H. Sabry-Neto \& M.V. Carmo-Sá. 2012. Spirulina meal has acted as a strong feeding attractant for Litopenaeus vannamei at a very low dietary inclusion level. Aquacult. Res., 43: 430-437.

Smith, D.M., S.J. Tabrett, M.C. Barclay \& S.J. Irvin. 2005. The efficacy of ingredients included in shrimp feeds to stimulate intake. Aquacult. Nutr., 11: 263272.

Suresh, A.V., K.P. Kumaraguru-Vasagam \& S. Nates. 2011. Attractability and palatability of protein ingredients of aquatic and terrestrial animal origin, and their practical value for blue shrimp, Litopenaeus stylirostris fed diets formulated with high levels of poultry by product meal. Aquaculture, 319: 132-140.

Tacon, A.G.J. 1989. Nutrición y alimentación de peces y camarones cultivados. Manual de Capacitación. Proyecto Aquila II. Documento de Campo No4, Brasilia, $100 \mathrm{pp}$.

Vaseeharan, B., G. Sai-Prasad, P. Ramasamy \& G. Brennan. 2011. Antibacterial activity of Allium sativum against multidrug-resistant Vibrio harveyi isolated from black gill-diseased Fenneropenaeus indicus. Aquacult. Int., 19: 531-539.

Vázquez-Ortiz, F.A., G. Caire, I. Higuera-Ciapara \& G. Hernández-Watanabe. 1995. High performance liquid chromatographic determination of free amino-acids in shrimp. J. Liq. Chromatrogr., 18: 2059-2068.

Velez, Z., P.C. Hubbarda, J.D. Hardegeb, E.N. Barataa \& A.V.M. Canário. 2007. The contribution of amino acids to the odour of a prey species in the Senegalese sole (Solea senegalensis). Aquaculture, 265: 336-342.

Zadeh, S.S., C.R. Saad, A. Christianus, M.S. Kamarudin, K. Sijam, M. Nor Shamsudin \& V.K. Neela. 2010. Assessment of growth condition for a candidate probiotic, Shewanella algae, isolated from digestive system of a healthy juvenile Penaeus monodon. Aquacult. Int., 18: 1017-1026.

Zar, J. 1999. Biostatistical analysis. Pearson International, London, 942 pp. 